\title{
Elżbieta Bogdanowicz
}

Uniwersytet w Białymstoku

\section{Wartości konotacyjne wybranych toponimów (na materiale publicystyki prasowej)}

Jedną z zasadniczych warstw leksyki każdego języka są nazwy własne (nomina propria, onimy). Definiuje się je na ogół jako wyrazy pozbawione treści językowej, czyli znaczenia leksykalnego ${ }^{1}$, służące do jednostkowej identyfikacji, tj. do wskazania (oznaczenia) danego obiektu indywidualnego w celu odróżnienia go od innych w realnej lub wyobrażonej rzeczywistości pozajęzykowej, współczesnej lub minionej bez względu na cechy, jakie są wspólne temu obiektowi oraz innym obiektom tak czy inaczej do niego podobnym [por. m.in. Grodziński 1973: 12; Superanskaja 1973: 113; Kaleta 1998: 18].

To powszechnie uznawane przez onomastów rozumienie nazw własnych uwydatnia dwa bardzo ważne ich atrybuty jako odrębnego bytu w systemie językowym. Pierwszym z nich jest pogląd, że nazwy nie mają znaczeń ${ }^{2}$. O ile bowiem wyraz lis zawiera zespół elementów składających się na jego treść znaczeniową (por. 'zwierzę ssące z rodziny psów', 'występuje w kilku gatunkach', 'najpospolitszy gatunek ma rude ubarwienie i długi ogon', 'żywi się gryzoniami, ptactwem', ‘żyje w Eurazji, północnej Afryce i Ameryce Północnej’ etc. Słownik języka polskiego [II, 1979: 41]), to np. nazwa Kasprowy Wierch nie znaczy nic, symbolizuje jedynie jednostkowy desygnat.

${ }^{1}$ Zgodnie $\mathrm{z}$ tradycyjnie akceptowanymi zasadami podziału jednostek leksykalnych nazwy własne przeciwstawiają się wyrazom pospolitym w planie semantycznym: nazwa własna - poza oznaczeniem i wyróżnieniem konkretnego obiektu spośród innych - nie implikuje żadnej cechy tego obiektu, i nie musi nieść ze sobą żadnej treści, wyraz pospolity natomiast nazywa przedmiot, przyporządkowując go do określonej klasy na podstawie wspólnej cechy lub zespołu wspólnych cech posiadanych przez wszystkie obiekty danej klasy, i w związku z tym coś o nim orzeka [Grodziński 1973: 13]. W konsekwencji nazwy własne nie mają znaczenia leksykalnego, choć można oczywiście podać opisy ich desygnatów, wyrazom pospolitym zaś takie znaczenie przysługuje.

${ }^{2} \mathrm{~W}$ opozycji do twierdzenia o zerowej semantyce nazw własnych stoi coraz częściej wypowiadany sąd, że nazwy nie tylko oznaczają, ale też znaczą [zob. np. Rzetelska-Feleszko 1988: 109-117; Kaleta 1998: 19-28; Rutkowski 2005: 99-110]. 
Druga, uwzględniona w przywołanej definicji, wręcz aksjomatyczna cecha propriów, to ich prymarna funkcja, tzw. funkcja identyfikacyjno-dyferencjacyjna ${ }^{3}$, zgodnie z którą rolą nazwy w języku jest równoczesne oznaczanie i wyróżnianie indywidualnych desygnatów, np. hydronim Wotga nie tylko identyfikuje określony denotat - rzekę w Rosji, ale i wyodrębnia go z całej klasy takich samych lub podobnych (ze zbioru nazw Wista, Laba, Tyber, Loara, Dniestr, Dunaj, Ren, Tamiza etc.).

Nazwy własne w przypisanej im w systemie językowym funkcji pojawiają się $\mathrm{w}$ felietonach, esejach, komentarzach, recenzjach, listach do redakcji (czyli formach dziennikarskiego przekazu tradycyjnie zaliczanych do publicystyki ${ }^{4}$ ) jako wyznaczniki obiektów jednostkowych różnego rodzaju: osób, miejscowości, gór, rzek, instytucji itd. Nie wyrażają przy tym żadnego znaczenia ${ }^{5}$. Jednak równie często onimy ustabilizowane w roli propriów w wyniku tzw. deonimizacji ${ }^{6}$ wychodzą poza tę rolę, stając się w konkretnych tekstach publicystycznych jednostkami znaczącymi. Nie jest to oczywiście znaczenie tożsame ze znaczeniem leksykalnym, ale znaczenie będące wynikiem interpretowania nazw własnych jako jednostek znaczących przez ich użytkowników.

Procesy interpretacyjne, którym podlegają nazwy własne, są sterowane strukturą onimu lub właściwościami denotatu, do którego onim odsyła. W pierwszym wypadku użytkownik języka dostrzega w nazwie własnej na zasadzie silnie odczuwanych zależności motywacyjnych między wyrazami fundującymi a nazwami pewną treść pojęciową i sądzi, że częściowo lub w całości przechodzi ona na denotat nazwy. Drugie źródło treści znaczeniowych onimu stanowi jego wartość konotacyjna, definiowana jako „utrwalony w świadomości społecznej (a więc powszechny, nie indywidualny) zbiór sądów i wyobrażeń o denotacie danej nazwy" [Kosyl 1983: 14]. Te sądy i opinie o denotacie mają często charakter zindywidualizowany, okazjonalny, ponieważ odzwierciedlają subiektywne postrzeganie na-

${ }^{3} \mathrm{~W}$ literaturze przedmiotu funkcja ta jest rozmaicie nazywana: najczęściej zamiennie używa się określeń funkcja identyfikacyjna, dyferencjacyjna lub identyfikacyjno-dyferencjacyjna [por. np. Kosyl 1992: 50]. Z. Kaleta [1998: 18] proponuje termin funkcja deiktyczna, a E. Pałuszyńska [2003: 115] - funkcja onomastyczna.

${ }^{4}$ Prasowe gatunki publicystyczne podporządkowane są funkcji interpretacyjnej i perswazyjnej, tzn. służą wyjaśnianiu, komentowaniu i ocenianiu rzeczywistości, ale także przeszłości i stawianiu hipotez co do przyszłości [Kozieł 2002: 119; Bauer 2000: 150].

${ }^{5}$ Nie mam tu na myśli tzw. ogólnego znaczenia kategorialnego propriów, czyli jednego atrybutu znaczeniowego, który odnosi nazywany obiekt indywidualny do danej kategorii obiektów, np. obiekt indywidualny nazwany Wisła należy do kategorii rzek, nazwa Kraków - do kategorii miast itd. W takim ujęciu nazwom własnym minimum znaczeniowe, czyli nie wyrażony w sposób widoczny zawarty w nich element semantyczny, przysługuje [Kaleta 1998: 24]. Tkwi ono w świadomości członków danej społeczności i składa się na ich wiedzę referencjalną, która stanowi część wiedzy o otaczającym świecie.

${ }^{6}$ Deonimizacją M. Rutkowski [2007: 31-32] nazywa utratę lub tylko osłabienie, naruszenie czy zawieszenie (choćby tylko incydentalne, tekstowe) związku denotacyjnego między nazwą i oznaczanym przez nią obiektem. 
zwy przez jej dowolnego użytkownika, w oryginalny sposób modyfikując obraz denotatu. I dlatego właśnie takie ulotne asocjacje, z natury swej nieustabilizowane, nie powinny pozostać poza polem opisu sfer konotacyjnych nazw. Przyjmuję zatem, że wartość konotacyjna jednostki onimicznej to „wiązka” pojedynczych konotacji (utrwalonych i okazjonalnych), które mówiący łączą z denotowanym obiektem.

Wszystkie typy propriów posiadają mniej lub bardziej rozbudowane znaczenia (wartości) konotacyjne. Poniżej, opierając się na przykładach pojawiających się w publicystyce prasowej w latach 2005-2012, chciałabym spróbować ustalić, jak przebiega proces konstruowania tego rodzaju znaczeń, jakie mechanizmy językowe są wykorzystywane i jakim przekształceniom ulegają nazwy własne (tu ograniczone do szeroko rozumianych toponimów) w trakcie formowania się semantycznych treści dodatkowych określanych mianem konotacji.

Konotacje nazw własnych ujawniają się w różnych użyciach wtórnych ${ }^{7}$ i odnoszą się do pozajęzykowej wiedzy o nazywanych obiektach. Warunkiem niezbędnym wytworzenia się konotacji ( $\mathrm{w}$ ostatecznej perspektywie wartości konotacyjnej) nazwy własnej jest posiadanie przez jej denotat wyrazistych cech odróżniających, dzięki którym zwraca on szczególną uwagę danej wspólnoty kulturowo-komunikatywnej i zostaje percepcyjnie wyróżniony przez członków tej wspólnoty - staje się nośnikiem określonych właściwości, ich wzorcowym reprezentantem, rodzajem etykiety dla danego denotatu. Np. ze zbioru cech, jakie użytkownicy łączą z denotatem nazwy miejscowej Waterloo (zob. 'miasto w Belgii położone niedaleko Brukseli', 'ośrodek turystyczny', 'miejsce słynnej bitwy, która odbyła się 15 czerwca 1815 r.', 'druzgocąca klęska wojsk francuskich pod wodzą Napoleona w starciu z armią koalicyjną Wellingtona i Blüchera’ itd.) na plan pierwszy wysuwa się utrwalone społecznie skojarzenie 'totalna przegrana, druzgocąca klęska', co znajduje odzwierciedlenie w następujących wystąpieniach tekstowych:

1) Waterloo Listkiewicza to pewna już utrata władzy i być może Euro 2012 [„,Wprost” 2008, nr 42];

2) Straszny lament podnióst się w kraju, gdy krakowska Wisła odpadła we wstęnnej rundzie kwalifikacji do piłkarskiej Ligi Mistrzów [...] Sympatyczny trener Wisty Maciej Skorża powiedział, że to było jego Waterloo. Bez przesady. Po to, by przeżyć swoje Waterloo, trzeba najpierw zostać Napoleonem [,Newsweek" 2009, nr 31];

${ }^{7}$ Użycia wtórne nazw własnych należą do pojęć pozasystemowych. S. Gajda [2004: 24] zalicza je do tzw. planu odonimicznego bytowania nazw, w którym następuje odchodzenie formy ustabilizowanej w funkcji proprium od tejże funkcji. Cz. Kosyl [1978: 136; 1983: 14] odnosi je wszystkie do metaforycznych użyć tekstowych. Natomiast T. Dobrzyńska [1992: 36] obdarza odnazewnicze użycia onimów określeniem antonomazji, która obejmuje proces uchylania związku denotacyjnego i wystapienie nazwy w nowej funkcji na zasadzie metonimii lub metafory.

8 Przykłady zaczerpnięto z publicystyki prasowej - z tygodników „Newsweek”, „Polityka”, „Wprost” i już zamkniętego tytułu „Ozon”. 
3) Waterloo Piłsudskiego [„,Wprost” 2006, nr 18] - [tekst pod tym tytułem zawiera ocenę przewrotu majowego w kategoriach porażki];

4) Z powodu projektu reformy ubezpieczeń zdrowotnych Obama dla wielu rodaków przestat już być bogiem i skurczyt się do ludzkich rozmiarów. [...] Obama ciagle wierzy, że uda mu się postawić na swoim. Na razie jednak bitwa o reformę systemu ubezpieczeń okazała się dla prezydenta prawdziwym Waterloo [,Wprost” 2009, nr 36];

5) Nikt też nie zakładat, że prezydentura Baracka Obamy zakończy się po trzech miesiacach klęska na miarę Waterloo [„,Wprost” 2009, nr 17];

6) A co jeśli bitwa z rakiem będzie Waterloo Chaveza? [„Polityka” 2012, nr 1].

Nomina propria nader często wykształcają konotacje. Zdaniem E. Otina [2006: 11] tendencja do nasycania jednostek onimicznych konotacjami jest zjawiskiem naturalnym i bardzo w języku rozpowszechnionym. Wskazywał już na to E. Grodziński [1973: 68] twierdząc, że propria mają większą ku temu skłonność niż nomina appellativa. Z tą opinią należy się zgodzić, ponieważ jednostkowa referencja, ograniczona tylko do jednego przedmiotu w rzeczywistości pozajęzykowej, powoduje, że przy bardzo wąskim zakresie nazwa własna ma szeroką treść, która podlega nieustannemu wzbogacaniu o nowe elementy. Ciagłe rozszerzanie się warstwy treściowej onimu jest wprost proporcjonalne do wiedzy użytkownika onimu na temat jego denotatu. Lepsze i głębsze poznanie nazwanego obiektu, czyli zgromadzenie wokół niego zestawu cech charakterystycznych, daje możliwość ich selektywnego porządkowania oraz wskazania dominującej cechy odróżniającej, która zaczyna funkcjonować jako silnie kojarzona $\mathrm{z}$ denotatem nazwy konotacja.

Konotacje łączone z nazwami własnymi różnią się nie tylko stopniem utrwalenia w świadomości wspólnoty kulturowo-komunikatywnej, lecz i zasięgiem występowania: międzyjęzykowym lub wewnątrzjęzykowym. Pierwsze z nich znane są członkom wielu społeczności mówiących różnymi językami, należących do jednego kręgu kulturowego, np. antycznego, chrześcijańskiego czy europejskiego. Konotacje wewnątrzjęzykowe zaś ograniczone są zasadniczo do jednego języka, a ściślej mówiąc, do jego odmiany ogólnej [Otin 2006: 14].

Podział umotywowany zasięgiem występowania dotyczy ustabilizowanych konotacji nazw własnych, czyli tych, które mają charakter uzualny, tzn. okres ich bytowania w danej wspólnocie kulturowo-komunikatywnej lub w społeczności mówiącej jednym językiem był na tyle długi, że nie są one tylko wynikiem przejściowej mody, ale mocno zakorzeniły się w tradycji, a przez to funkcjonują na zasadzie pewnych stereotypów. Wyrazem stabilności tego rodzaju konotacji są poświadczenia w faktach czysto językowych: w utartych związkach frazeologicznych, przysłowiach, porzekadłach itd. Świadectwem ostatecznego utrwalenia się określonej konotacji nazewniczej kryjącej się za jednostką onimiczną jest przesunięcie nazwy do klasy wyrazów pospolitych nazywane apelatywizacją ${ }^{9}$ z jednoczesnym przypisaniem tej nazwie znaczenia leksykalnego wykształconego

${ }^{9}$ Apelatywizacja to proces stawania się nazwy własnej wyrazem pospolitym [Długosz-Kurczabowa 1990: 69; Cieślikowa 2006: 51; Rudnicka 2006: 192]. 
z konotacji. Na przykład z toponimu Eldorado z wiązką cech kojarzonych typu 'legendarna kraina obfitująca w złoto', 'miejsce poszukiwane nadaremnie przez hiszpańskich konkwistadorów', 'obszar leżący prawdopodobnie między Amazonką i Orinoko’ [Kopaliński 2004: 77] wywodzi się apelatyw eldorado ze znaczeniem leksykalnym 'kraj opływający w bogactwa, wymarzona kraina szczęścia i dobrobytu, ziemia obiecana, raj', zarejestrowany leksykograficznie [Stownik języka polskiego 1978, t. I: 531]. Źródłem definicji słownikowej wyrazu pospolitego eldorado jest wyróżniona w obiegu społecznym jedna z cech konotacyjnych, pierwotnie łączona z toponimem - bazą motywującą. Dużą popularność tej konotacji, skodyfikowanej w znaczeniu leksykalnym, potwierdzają liczne wypowiedzi prasowe (aż 15 cytatów):

7) Grecja mogłaby być turystyczno-rolniczym eldorado. Chodzi o to, żeby ludziom pokazać światelko w tunelu [„Newsweek” 2012, nr 20];

8) Jak twierdza przedstawiciele organizacji zrzeszajacych firmy turystyczne, przy niskim kursie złotego Polska zaczyna się jawić niczym eldorado dla Europejczyków i Amerykanów [„Newsweek” 2009, nr 16];

9) Panuje [...] przekonanie, że jeśli rosyjski gaz musimy kupować, to nasz, lupkowy, będziemy mieli za darmo. Dlatego stychać wiele głosów oburzenia, że do polskiego gazowego eldorado dopuszczamy Amerykanów [„Polityka” 2010, nr 27];

10) Partie polityczne w Polsce sa przedsiębiorstwami. Kiedy partia wciśnie narodowi swój produkt (czyli samq siebie), dostaje od nas kilkadziesiat milionów złotych rocznie. Wejście partii do parlamentu staje się finansowym eldorado [,,Wprost” 2010, nr 31];

11) Prawdziwe geotermiczne eldorado odkryto jednak na antypodach. [...] odkryto najgorętsze śródkontynentalne skały na świecie [„Polityka” 2010, nr 9];

12) Singapur [...] ma być prawdziwym eldorado dla ludzi nauki z całego świata oraz wizytówkq możliwości Singapuru [„,Polityka” 2008, nr 50];

13) Dania, chociaż nigdy nie uchodziła za piłkarskie eldorado, była dla młodego zawodnika sportowym awansem i kolejnym w jego karierze krokiem w przód [„Newsweek” 2010, nr 48];

14) Prawdziwe samochodowe eldorado $w$ branży używanych trwa od 2004 r., czyli od naszego wejścia do UE [,Polityka” 2009, nr 14];

15) Rzadzace Azerbejdżanem elity chca, by naftowe eldorado prędko się nie skończyto. Dzięki ropie wciaż niezbyt zamożna republika notuje rekordowe tempo wzrostu gospodarczego [„Newsweek” 2008, nr 48];

16) To było dobre państwo, opiekuńcze. [...] Do budowy lub kupna domków jednorodzinnych kasa federalna doktadała Niemcom przez kilka dziesiatków lat duże pieniadze. W 2005 -ostatnim roku tego eldorado - kosztowało to budzet federalny 10 mld euro [„Newsweek” 2008, nr 49];

17) Po wieloletnim eldorado, finansowanym z pieniędzy klientów, banki płacq za grzech pazerności. Kara w postaci topniejących zysków będzie surowa [„Newsweek” 2009, nr 19];

18) Inaczej naszq obecność w Schengen postrzegaja mieszkańcy polskiej ściany wschodniej: to tutaj zamknięto wiele bazarów, na których kwitt handel z Ukraińcami i Białorusinami. Skończyło się eldorado czy choćby tylko praca dająca możliwość normalnego życia [...] [„,Polityka” 2010, nr 15];

19) Eldorado kredytowe w Polsce byto krótkie, ale intensywne. Skończyło się ponad rok temu wraz z wybuchem światowego kryzysu finansowego [„Polityka” 2009, nr 49];

20) Eldorado hydraulików, czyli duże przebicie na płacach za ustugi $\mathrm{np}$. w Irlandii czy Anglii w porównaniu z tym, co można było zarobić w Polsce, właśnie się skończyło [„Polityka” 2010, nr 30]; 
21) Rolnicy rzeczywiście ucierpieli. W czasie hiperinflacji sprzedawali wszystko na pniu, przyszedł Balcerowicz i eldorado się skończyło. A potem jeszcze wielu wrzucono w pułapkę kredytowa [,Newsweek” 2010, $\mathrm{nr} 2]$.

Za konotacje odznaczające się wysokim stopniem ustabilizowania w systemie językowym uznawane są przede wszystkim te, które stanowią część wartości konotacyjnych nazw własnych wywodzących się z kultury antycznej i chrześcijańskiej. Proces utrwalania się konotacji nazewniczych o proweniencji mitologicznej lub biblijnej wsparty jest długotrwałym okresem bytowania onimów w kulturze, a co za tym idzie i wielowiekową tradycją użycia. Tego rodzaju konotacje w licznych przypadkach przekształciły się już w znaczenia leksykalne częściowo lub zupełnie zapelatywizowanych onimów, są dobrze znane członkom danej wspólnoty społecznej i aktywne na różnych płaszczyznach komunikacji językowej. Wyrazistym przykładem takiego znaczenia, mającym poświadczenia w tekstach publicystycznych, jest 'piedestał; wysoka pozycja w jakiejś dziedzinie' wyodrębniony z pozajęzykowej wiedzy o desygnacie oronimu Olimp, który według wierzeń starożytnych Greków odnosił się do świętej góry - głównej siedziby greckich bóstw:

22) W czasach, gdy znaczenie maja jedynie ugrupowania zwarte, oparte na autorytecie lidera, politycy niezależni sq z trudem tolerowani, a często wylatuja z partii. W ostatnim czasie tak stało się chociażby z Janem Rokita czy Ludwikiem Dornem. Obaj z politycznego Olimpu w mgnieniu oka spadli na dno [,Newsweek” 2009, nr 13];

23) [...] jako szczególnie wrażliwy nie radzit sobie [Michel Jackson] z rozrzedzonym ciśnieniem na wierzchołku współczesnego Olimpu, gdzie w thumie wyznawców trudno rozróżnić prawdziwych przyjaciót [„,Polityka” 2009, nr 27];

24) Elżbieta [Czyżewska, polska gwiazda filmowa i teatralna w latach 60. XX w., która wyemigrowała do USA, i to był koniec jej wielkiej kariery] grała, ale nie na Broadwayu, nie tam, gdzie marzy każdy aktor czy aktorka, zwłaszcza jeśli byt już kiedyś na Olimpie [„,Polityka” 2012, nr 6];

25) ,Taniec z gwiazdami” dał nam znacznq grupę ludzi, którzy zasiedlili kulturowy Olimp Rzeczypospolitej. Takie nazwiska jak Maserak, Kajak, Hakiel, Kochanek czy Kiszka wymieniamy jednym tchem obok nazwisk Szymborska [...] [„,Polityka” 2009, nr 8];

26) O ile jednak komisja śledcza ds. afery Rywina wyniosła go na polityczny olimp, to stynny gwóźdź - dyktafon z nagraniem Andrzeja Leppera - byt poczatkiem załamania. Dwa miesiqce później odbyly się wybory parlamentarne, które PiS przegrało i Ziobro musiał odejść ze stanowiska [„Newsweek” 2008, nr 37];

27) Od poczqtku października ponad setka młodych pianistów z całego świata przez prawie trzy tygodnie będzie się starała uwodzić komisję i publiczność konkursu [...] Odbywa się co pięć lat [Międzynarodowy Konkurs Chopinowski], a dla młodych pianistów jest muzycznym olimpem, który może odmienić ich życie [,Newsweek” 2010, nr 39].

Na podobnych zasadach funkcjonują konotacje związane z nazwami miejscowości Sodoma i Gomora o pierwotnej denotacji w Biblii, które zazwyczaj występują w tekstach łącznie. Możliwe jest także rozdzielenie tego wyrażenia i samodzielne występowanie jednego z członów przy zachowaniu identycznych znaczeń. Do tych całkowicie ustabilizowanych w roli apelatywów propriów odno- 
szą się ujęte w słowniku znaczenia - pochodne konotacji nazewniczych: 'wielkie zamieszanie, rozgardiasz, awantura' oraz 'rozpusta, niemoralne postępowanie' [Stownik języka polskiego 1978, t. I: 677; 1981, t. III: 271-272], które aktualizują się w następujących wypowiedziach prasowych:

28) Doszedtem do Żelazowej Woli. Druciany płot otaczat park. [...] Wspiatem się i przeskoczytem przez płot. We dworze - sodoma i gomora. Siano, puszki po konserwach $w$ fortepianie [,Newsweek” 2010, nr 29];

29) Mielno nazywane było kiedyś polska Ibiza. Dziś bardziej przypomina biblijna Sodome $i$ Gomore [„Newsweek” 2008, nr 30];

30) W tej kronice wspótczesnej Sodomy i Gomory (chodzi o film F. Felliniego „Słodkie życie”) najbardziej groteskowa postacia jest grany przez Marcello Mastroianniego dziennikarz, trwoniacy swój pisarski talent na redagowanie rubryki towarzyskiej w wysokonakładowym piśmie [„Polityka” 2009, nr 15];

31) My tu chcemy mieć spokój, a nie takq Sodomę i Gomorę jak w Krakowie. Tam po rynku nago ganiaja [,Polityka” 2009, nr 29];

32) Jak komuś się wydaje, że tylko w polskim senacie panuje Sodoma, Gomora $i$ wciaganie lekarstw nosem, to się myli. W amerykańskim jest jeszcze gorzej [„Newsweek” 2010, nr 20];

33) [...] w tym Sejmie to jest jakaś Sodoma. Pytanie brzmi, gdzie jest Gomora? W Senacie? W Kancelarii Premiera? Bo przecież nie w pałacu prezydenckim [„Newsweek” 2009, nr 47];

34) Neapol w filmie Garonnego w niczym nie przypomina stonecznego miasta z turystycznych widokówek. To brudne slumsy - nowe wcielenie biblijnej Gomory [,Wprost” 2009, nr 3] ${ }^{10}$.

Inny toponim biblijny Golgota z zestawem sądów o nazywanym obiekcie (np. 'wzgórze pod Jerozolimą', 'miejsce ukrzyżowania i cierpienia Chrystusa') również jest źródłem powszechnie znanego w języku znaczenia 'cierpienie, męka, ból, męczeństwo; cierpienie moralne’ [Kopaliński 2004: 107]:

35) Widziałam, że moje cierpienie jest niczym w porównaniu z tym, co przechodzq inne kobiety, z którymi się zaprzyjaźniłam. To była, nie waham się użyć tego stowa, ich prawdziwa golgota. Najpierw wielka niepewność w oczekiwaniu w kolejce na zabieg, następnie na wynik, potem męka chemioterapii czy radioterapii, a po roku, dwóch powrót do szpitala, by sprawdzić, czy leczenie przyniosto oczekiwany skutek [,Wprost” 2009, nr 15];

36) [...] fragment dawnego poligonu NKWD w Butowie pod Moskwa, który byt głównym miejscem kaźni ofiar wielkich stalinowskich czystek lat 1937-38 (rozstrzelano tam ponad 20 tys. osób, w tym tysiac duchownych, a także około tysiaca naszych rodaków). To miejsce, które Cerkiew nazywa rosyjska Golgota [...] [,Polityka” 2010, nr 15];

37) Golgota chrześcijan [tym tytułem opatrzony został artykuł prasowy o trudnych losach i sytuacji wspólnot chrześcijańskich w krajach muzułmańskich] [„Newsweek” 2010, nr 14].

Wysokim poziomem utrwalenia odznaczają się także konotacje kojarzone z nazwami geograficznymi uwzględnianymi w składzie tradycyjnych związków frazeologicznych. Nazwy te mogą uwolnić się ze struktur frazeologizmów wraz z konotacją, która następnie jest przekształcana w określoną wartość znaczeniową.

${ }^{10}$ Inne przykłady prezentujące użycie jednostek Sodoma i Gomora w roli apelatywów z przypisanymi im stałymi znaczeniami zawiera praca M. Rutkowskiego [2007: 151-152]. 
Przykładowo: na podstawie idiomu przekroczyć Rubikon 'uczynić krok decydujący, nieodwołalny; spalić za sobą mosty' [Kopaliński 2004: 234] uformowała się jednostka Rubikon 'stanowczy krok, nieodwołalna, nie dająca się cofnąć decyzja':

38) Homo sapiens istotnie się zmienit wraz z przemianq łowców-zbieraczy w rolników. [...] Dla ludzkości byt to ekologiczny Rubikon [„Wprost” 2009, nr 5].

Konotacje ustabilizowane związane są też z oronimami Himalaje i Mount Everest oznaczającymi odpowiednio najwyższe pasmo górskie na świecie i najwyższą górę świata. W obu przypadkach jest to ta sama dominująca konotacja 'szczyt, najwyższy stopień czegoś; rekordowa wysokość', wyrażona za pośrednictwem nazw w następujących fragmentach tekstów publicystycznych:

39) Moje żarty z premiera sq Himalajami dobrego smaku w porównaniu z tym, jak posłowie PO mówiq o prezydencie czy o PiS [,Wprost” 2009, nr 50];

40) Niedawno, gdy prosiłem stronę amerykańskq o uwzględnienie naszych potrzeb w dziedzinie bezpieczeństwa, czołowy przywódca opozycji określit to Himalajami niekompetencji [„,Newsweek” 2008, nr 5];

41) [...] szeroko opisywana i komentowana sprawa Polańskiego wyczerpała już limit publicznych samobójstw, strzałów w stopę, głupot i zwyktej hipokryzji. Jednak pański tekst osiagnąt Himalaje wszelkiego zaktamania [,Newsweek” 2009, nr 41];

42) Wtedy nie śniło mi się, że $w$ tej sprawie poziom hipokryzji sięgnie Himalajów [...] [,Wprost” 2009, nr 14];

43) Najwięcej szumu było wokót Radka Sikorskiego, który dla jednych jest doskonatym fachowcem, a dla drugich reprezentuje „Mount Everest niekompetencji”. Dobrze, że sq na świecie góry większe niż polskie Tatry, bo określenie ,, Giewont niekompetencji”, „,Nosal niekompetencji” czy ,, Gubałówka niekompetencji” nie miałoby takiej mocy [,,Wprost” 2007, $\mathrm{nr} 46$ ];

44) Ta wizyta była Mount Everestem braku profesjonalizmu i infantylizmu Sikorskiego - ocenit tymczasem Jarosław Kaczyński. Jego zdaniem, ówczesny szef MON w zamian za zgodę na tarczę rakietowa żądał od USA nierealistycznej pomocy finansowej [„,Wprost” 2007, $\mathrm{nr} 45$ ];

45) Rostowski tworzy Mount Everesty chaosu w Europie [...] [„,Wprost” 2011, nr 38].

Kolejny cytat prasowy z udziałem jednostki toponimicznej Mount Everest pokazuje, że w z jej struktury konotacyjnej wyodrębnia się jeszcze jedna cecha asocjacyjna 'wyzwanie'"11:

46) Widać już pierwsze jaskótki. [...] Płock byt pierwszym miastem w Polsce, które zaproponowało elastyczne godziny pracy przedszkoli. Wcześniej zamykano je o godz. 16, co dla dlugo pracujacych rodziców stawało się logistycznym Mount Everestem. Także prywatne firmy staraja się ułatwić Polakom rodzicielstwo [„,Wprost” 2008, nr 2];

47) Zdobywanie Mount Everestu nie jest bezbolesne. Gdyby nie było upadków, od czego mielibyśmy się odbijać? Tym Mount Everestem w pańskiej karierze co byto? Nowy Jork. Manhattan. Zostat zdobyty, pokochany. Już pierwszy krok na lotnisku Kennedy'ego potwierdzit wszelkie moje przeczucia i marzenia [,Polityka” 2012, nr 46].

${ }^{11}$ Interesujących przykładów poświadczających obecność konotacji ‘wyzwanie' w zakresie wartości konotacyjnej oronimu Mount Everest dostarcza W. Chlebda [2000: 252]. 
Nieco inny charakter mają konotacje ustabilizowane o zasięgu wewnątrzjęzykowym, ponieważ obejmują opinie i sądy o denotatach nazw własnych, które są dobrze osadzone w świadomości jednego narodu (tu: polskiego) i powszechnie znane wśród większości jego członków, np.: z nazwą miejscową Oświęcim//Auschwitz $w$ sposób stały związana jest konotacja 'miejsce kaźni, zbrodni, okrutnego traktowania ludzi, znęcania się nad nimi’, jednostki nazewnicze Katyń i Gibraltar symbolizują z kolei 'polską tragedię, ofiarę, cierpienie', w pierwszym przypadku motywowaną mordem Rosjan (NKWD) dokonanym na polskich jeńcach wojennych i więźniach, w drugim zaś katastrofą lotniczą, która zdaniem historyków miała ukryć skutki wcześniejszego zamachu na gen. Władysława Sikorskiego, premiera i Naczelnego Wodza Polskich Sił Zbrojnych. Powyższe konotacje ilustrują przykłady w rodzaju:

48) [...] lekarze z leningradzkiej psychuszki na co dzień mówili o niej czule „nasz mały Oświęcim” [ze względu na torturowanie pacjentów, które często doprowadzało do śmierci] [„Newsweek” 2010, nr 6];

49) Dlaczego Auschwitz? Bo nazwa ta jest symbolem niemieckich zbrodni w II wojnie światowej [„Wprost” 2009, nr 24];

50) Komorowski będzie petnić urzad w bardzo trudnym psychologicznie momencie, gdy świeża będzie pamięć o katastrofie, która wydarzyła się w niezwyktych okolicznościach, której już próbuje się nadać wymiar symboliczny, mówiac o drugim polskim Katyniu czy Gibraltarze [„Polityka”2010, nr 16].

Obok konotacji odznaczających się wysokim stopniem ustabilizowania do wartości konotacyjnej nazwy własnej należą też luźne skojarzenia wynikające z bardzo indywidualnego postrzegania denotatu wyznaczanego przez tę nazwę, tzw. konotacje okazjonalne, ściśle tekstowe. Takich konotacji obiektom nazywanym za pomocą różnorodnych nazw własnych - pośrednio także nazwom - przypisuje się bardzo wiele. Dość często odwołują się do nich dziennikarze prasowi, którzy na bazie tych zindywidualizowanych, okazjonalnych asocjacji jednostek proprialnych, kreują niepowtarzalne konstrukcje tekstowe, np.:

51) Będzin nazywano przed wojna mała Jerozolima, a zdarzało się $w$ dziejach miasta, że liczba Żydów dochodziła do 80 procent [,Polityka” 2010, nr : 38]; konotacja ‘skupisko ludności żydowskiej';

52) [...] stanie się cywilizacyjnq czarnq dziura, jak Afganistan [„Newsweek” 2011, nr 6]; konotacja 'kraj gospodarczo i cywilizacyjnie zacofany';

53) Atmosfera wokót gazu tupkowego przypomina trochę tę, która panowała w Polsce w 1980 r., gdy w Karlinie koło Koszalina trysnęła ropa. Cała Polska emocjonowała się wówczas myśla, że być może żyjemy na wielkich złożach ropy i jesteśmy drugim Kuwejtem [„,Polityka” 2010, nr 21]; konotacja 'kraj zasobny w ropę naftową';

54) [...] Łódź - polski Manchester” [„Wprost” 2007, nr 21]; konotacja “ośrodek przemysłu włókienniczego';

55) Bałuty [dzielnica Łodzi] będa polskim Brooklynem, tylko trochę bezpieczniejszym [...] [„Wprost” 2009, nr 8]; konotacja 'dzielnica niebezpieczna, z rozwiniętą przestępczością’;

56) Żeby zobaczyć, czy takie same emocje zespót wywoła u Chińczyków, przed wyjazdem za Wielki Mur Bayer Full zagra koncert w polskim Chinatown w Wólce Kosowskiej pod Warszawa [,Newsweek” 2010, nr 41]; konotacja 'dzielnica lub miejscowość zamieszkała przez mniejszość azjatycką, głównie z Chin'; 
57) Marzenia Litwinów, Łotyszy i Estończyków o szybkim zbudowaniu drugiej Skandynawii spetzly na niczym, bo złamali podstawowq zasade, jakiej hołduja tamte przedsiębiorcze społeczeństwa: nie wydawaj więcej, niż zarabiasz [„,Newsweek” 2009, nr 5]; konotacja 'kraj lub obszar wysoko rozwinięty gospodarczo i ekonomicznie';

58) Jak doszło do tego, że Bułgaria zyskała miano Sycylii Bałkanów? [...] Zabójstwa na zlecenie staty się najskuteczniejszym i najtańszym sposobem rozwiazywania poważnych problemów ekonomicznych [...] Jednocześnie kwitt przemyt - samochodów (Bułgaria stata się cudownym rynkiem na skradzione auta), papierosów, alkoholu. Mafia się bogaciła, a przestępcy żyli dostatniej [„Polityka” 2009, nr 46]; konotacja 'kraj opanowany przez mafię';

59) Ale mała Moskwa nad Tamizq to nie tylko miliarderzy. Do Londynu ściagnęty tysiace przedstawicieli rosyjskiej klasy średniej, ludzi zamożnych i dobrze wyksztatconych [„Newsweek” 2010, nr 40]; konotacja 'skupisko ludności rosyjskiej';

60) Polska jak Argentyna [skutki wejścia Andrzeja Leppera do rządu porównane do kryzysu argentyńskiego] [Ozon 2005, nr 16]; konotacja 'krach ekonomiczny i gospodarczy';

61) Janukowycz depcze opozycję, wolność słowa i prawa człowieka. Ukraina zaczyna być nazywana „Bialorusiq, tyle że nastawiona na UE” [„Newsweek” 2011, nr 34]; konotacja 'kraj, w którym represjonowani są obywatele za poglądy sprzeczne z prowadzoną przez władzę polityką';

62) Nie ukrywat, że Węgry, które za poprzedniego rzqdu zwrócity się do Międzynarodowego Funduszu Walutowego o 25 mld dolarów pomocy finansowej, czekajq drastyczne cięcia wydatków. Przez moment wydawało się, że kraj skazany jest na gospodarcze tapnięcie, które zamieni go w drugq Grecje [„,Wprost” 2010, nr 42]; konotacja 'kraj ogarnięty kryzysem gospodarczym i ekonomicznym'.

Zamykając rozważania na temat relacji nazwy własne a wartości konotacyjne warto podkreślić, że nasycone konotacjami jednostki onimiczne w konkretnych tekstach mogą znaczyć, tj. być nośnikami różnorodnych treści. Ta nabyta semantyka nie jest oczywiście właściwością systemową nazw własnych, ale otwiera nowe, interesujące kierunki ich badania i interpretowania.

\section{Bibliografia}

Bauer Zbigniew, 2000, Gatunki dziennikarskie, [w:] Zbigniew Bauer, Edward Chudziński (red.), Dziennikarstwo i świat mediów, Kraków, 150-158.

Chlebda Wojciech, 2000, Ile jest Mławy w Mławie? Pochodne nazw własnych w językowym obrazie świata Polaków, „Język a kultura”, t. 13, 247-259.

Cieślikowa Aleksandra, 2006, Onimizacja, apelatywizacja a derywacja, [w:] Zofia Abramowicz, Elżbieta Bogdanowicz (red.), Onimizacja i apelatywizacja, Białystok, 47-56.

Długosz-Kurczabowa Krystyna, 1990, Apelatywizacja biblijnych nazw własnych w języku polskim, Wrocław.

Dobrzyńska Teresa, 1992, Nazwy własne w użyciach tropicznych. Casus antonomazji, [w:] Teresa Dobrzyńska (red.), Studia o tropach II, Wrocław, 27-39.

Gajda Stanisław, 2004, Narodowokulturowy składnik znaczenia nazw własnych $w$ aspekcie edukacyjnym, [w:] Robert Mrózek (red.), Nazwy własne w języku, kulturze i komunikacji społecznej, Katowice, 21-28.

Grodziński Eugeniusz, 1973, Zarys ogólnej teorii imion własnych, Warszawa.

Kaleta Zofia, 1998, Teoria nazw własnych, [w:] Ewa Rzetelska-Feleszko (red.), Polskie nazwy własne. Encyklopedia, Warszawa-Kraków, 15-36. 
Kopaliński Władysław, 2004, Słownik eponimów, czyli wyrazów odimiennych, Warszawa.

Kosyl Czesław, 1978, Metaforyczne użycie nazw własnych, [w:] Mieczysław Szymczak (red.), Z zagadnień słownictwa wspótczesnego języka polskiego, Wrocław, 133-143.

Kosyl Czesław, 1983, Forma i funkcja nazw własnych, Lublin.

Kosyl Czesław, 1992, Nazwy własne w prozie Jarosława Iwaszkiewicza, Lublin.

Kozieł Andrzej, 2002, Gatunki dziennikarskie - rodowód, cechy, funkcje, [w:] Janusz Adamowski (red.), O warsztacie dziennikarskim, Warszawa, 115-120.

Otin Evgenij Stepanovič, 2006, Slowar konnotatiwnych sobstwennych imen, Moskwa-Donieck.

Pałuszyńska Edyta, 2003, Nazwy własne w funkcji nieonomastycznej, [w:] Maria Biolik (red.), Metodologia badań onomastycznych, Olsztyn, 115-120.

Rudnicka Ewa, 2006, Eponizmy versus eponimy. Eponizmy jako efekt mechanizmu apelatywizacji eponimów, [w:] Zofia Abramowicz, Elżbieta Bogdanowicz (red.), Onimizacja i apelatywizacja, Białystok, 185-199.

Rutkowski Mariusz, 2005, Kilka uwag o konwencjach opisu wartości semantycznej nazw własnych, „Onomastica” t. L, 99-110.

Rutkowski Mariusz, 2007, Nazwy własne w strukturze metafory i metonimii, Olsztyn.

Rzetelska-Feleszko Ewa, 1988, Znaczenie nazw własnych w procesie komunikacji językowej, [w:] Karol Zierhoffer (red.), V Ogólnopolska Konferencja Onomastyczna (Poznań 3-5 września 1985). Księga referatów, Poznań, 109-117.

Słownik języka polskiego, 1978-1981, Mieczysław Szymczak (red.), t. I-III, Warszawa.

Superanskaja Aleksandra Vasil'evna, 1973, Obszczaja teorija imeni sobstwennogo, Moskwa.

\section{Elżbieta Bogdanowicz}

\section{Connotative values of selected toponyms (based on press journalism)}

\section{(Summary)}

Proper names signify single words of all kinds: people, places, mountains, rivers, institutions, etc. However, they do not reflect meanings. As a result of deonymisation, i.e. loosening of denotative associations between the word and the object denoted by it, proper names become meaningful units. Their connotative value, or a number of concepts and ideas, about the denotat which the onym refers to, is an important source of semantic content. Semantics viewed in this way puts a new perspective on research in proper names. The article shows the results of a research on the broadly defined toponyms, such as Waterloo, Eldorado, Mount Olympus, the Himalayas, Auschwitz, Brooklyn, Belarus appearing in the press in 2005-2012 in a variety of contexts, where the literary meaning in a toponymic form changes. Consequently, accumulation of additional semantic content in fixed or occasional connotative forms occurs.

Słowa kluczowe: wartość konotacyjna, nazwa własna (toponim), deonimizacja, konotacja utrwalona, konotacja okazjonalna.

Keywords: connotative value, proper name (toponym), deonymisation, fixed connotation, occasional connotation. 